\title{
Utility of S-100B as a Potential Tool for Neuromonitoring and Prediction of Neuroworsening in Acute Phase of Traumatic Brain Injury
}

\author{
Alexander Rodríguez ${ }^{1}$, Eliana Cervera ${ }^{2}$, Gigliola Macchia ${ }^{3}$, Xilene Mendoza ${ }^{4}$, Walter Martínez ${ }^{5}$, Osmar Pérez $^{6}$, \\ Homero Sanjuán ${ }^{7}$, Pedro Villalba ${ }^{8}$
}

\begin{abstract}
Aim: In this review, we summarize the evidence on the use of S-100B in traumatic brain injury (TBI) of all severities, its clinical significance, and its prognostic value in the different posttrauma phases.

Background: Most of the published studies report the serum determination of S-100B in the context of mild TBI as a predictor of positive CT scan, which represents a valuable tool when establishing a criterion to indicate the performance of the CT and decide the medical discharge. Likewise, we have reported several studies that correlate S-100B with the clinical evolution of the patient with severe TBI, showing an excellent indicator of intracranial hypertension. However, there are few studies that report on the impact of S-100B as a predictor of neuroworsening in the acute phase in moderate TBI.

Review results: Traumatic brain injury comprises a heterogeneous group of traumatic injuries that can evolve progressively. Almost $90 \%$ of head injuries that reach the hospital are mild head injuries or mild TBI, which is defined by a score of more than 12 on the Glasgow Coma Scale (GCS). Of this, a few can be accompanied by a hemorrhagic lesion that can be detected by further imaging techniques. Still, utilizing these techniques in every single patient that comes to the ER does not only take a toll on the finances of the hospital but, more importantly, also exposes the patients to unnecessary radiation. There are still difficulties to correlate the findings on imaging with secondary injury, and to predict the clinical evolution in the acute phase and in the long-term. Serum S-100B levels have shown high sensibility and negative predictive value (NPV) for intracranial complications after mild head injury. Most of the published studies report that measurement in serum of S-100B in the context of mild TBI, as a predictor of CT findings, represents a valuable tool when establishing a criterion for indication of CT and to decide medical discharge. However, there are few studies that report the impact of S-100B as a predictor of neuroworsening in the acute phase of moderate TBI, which is defined by a score between 9 and 12 on the GCS.
\end{abstract}

Conclusion: Serum S-100B is a useful marker of brain damage in TBI. Its usefulness has been studied mainly as a support to evaluate the need to perform a CT scan in mild TBI, and to monitor patients with moderate-to-severe TBI, in order to predict the outcome and validate the response to treatment. This review highlights S-100B as a versatile marker whose clinical utility depends on the severity of the head trauma. In this way, S-100B would be a potential predictor of neuroworsening in the acute phase in moderate TBI.

Clinical significance: Despite its valuable utility as a predictor of positive CT in mild TBI, and as a tool for neuromonitoring in established severe $\mathrm{TBI}$, the greater utility of S-100B could be as a predictor of neuroworsening in the acute phase in the moderate TBI.

Keywords: Brain injuries, Intracranial hypertension, Neuromonitoring, Prognosis, S-100B.

\section{Resumen}

Objetivo: En esta revisión resumimos la evidencia sobre el uso de S-100B en el trauma craneoencefálico (TCE) de todas las severidades, su significado clínico y su valor pronóstico en las diferentes fases postraumáticas.

Antecedentes: la mayoría de los estudios publicados reportan la medición sérica de S-100B en el contexto del TCE leve como predictor de TAC de cráneo positiva, lo que representa una valiosa herramienta a la hora de establecer un criterio para indicar una TAC y decidir el alta médica. Asimismo, varios estudios correlacionan a S-100B con la evolución clínica del paciente con TCE grave, mostrando ser un excelente indicador de hipertensión intracraneal. Sin embargo, existen pocos estudios que informen sobre el impacto de S-100B como predictor de empeoramiento neurológico en la fase aguda del TCE moderado.

Resultados: la lesión cerebral traumática comprende un grupo heterogéneo de lesiones que pueden evolucionar progresivamente. Casi el $90 \%$ de los traumas craneoencefálicos que llegan al hospital son leves, lo cual se define por una puntuación de más de 12 en la Escala de coma de Glasgow (ECG). De estos, algunos pueden ir acompañados de una lesión hemorrágica que puede detectarse mediante otras técnicas de imagen. Aun así, la utilización de estas técnicas en cada paciente que llega a la sala de emergencias no solo afecta las finanzas del hospital, sino que, más importante aún, expone a los pacientes a radiación innecesaria. Sigue habiendo dificultades para correlacionar los hallazgos de las imágenes con la lesión secundaria y para predecir la evolución clínica en la fase aguda y a largo plazo. Los niveles séricos de S-100B han mostrado una alta sensibilidad y un valor predictivo negativo (VPN) para las complicaciones intracraneales después de un trauma craneoencefálico leve. La mayoría de los estudios publicados informan que la medición en suero de S-100B en el contexto de un TCE leve, como predictor de hallazgos en la TAC, representa una herramienta valiosa a la hora de establecer un criterio de indicación de TC y para decidir el alta médica. Sin embargo, existen pocos estudios que reporten el impacto del S-100B como predictor de empeoramiento neurológico en la fase aguda del TCE moderado, el cual se define por una puntuación entre 9 y 12 en la ECG.

Conclusión: S-100B sérico es un marcador útil de daño cerebral en el TCE. Su utilidad se ha estudiado principalmente como soporte para evaluar la necesidad de realizar una TAC en el TCE leve, y para monitorizar a los pacientes con TCE moderado-grave, con el fin de predecir el resultado y

(-The Author(s). 2020 Open Access This article is distributed under the terms of the Creative Commons Attribution 4.0 International License (https://creativecommons. org/licenses/by-nc/4.0/), which permits unrestricted use, distribution, and non-commercial reproduction in any medium, provided you give appropriate credit to the original author(s) and the source, provide a link to the Creative Commons license, and indicate if changes were made. The Creative Commons Public Domain Dedication waiver (http://creativecommons.org/publicdomain/zero/1.0/) applies to the data made available in this article, unless otherwise stated. 
validar la respuesta al tratamiento. Esta revisión destaca al S-100B como un marcador versátil cuya utilidad clínica depende de la gravedad del traumatismo craneal. De esta forma, el S-100B sería un potencial predictor de empeoramiento neurológico en la fase aguda en el TCE moderado. Importancia clínica: a pesar de su valiosa utilidad como predictor de TAC positiva en el TCE leve y como herramienta de neuromonitorización en el TCE severo establecido, la mayor utilidad de S-100B podría ser como predictor de empeoramiento neurológico en fase aguda del TCE moderado.

Palabras clave: Lesiones cerebrales traumáticas, Hipertensión intracraneal, Monitorización, Pronóstico, S-100B.

Panamerican Journal of Trauma, Critical Care \& Emergency Surgery (2020): 10.5005/jp-journals-10030-1288

\section{BACKGROUND}

The term "biomarker" refers to biological substances that serve as indicators of occurrence, status, and/or evolution of a disease or pathological condition. Qualitatively or quantitatively, biomarkers can be measured by molecular biology, chromatographic, spectroscopic, optical, and electrochemical techniques, from tissue samples or body fluids. ${ }^{1,2}$ Specifically, in traumatic brain injury (TBI), the use of biomarkers is proposed as an alternative and/or complement to current diagnostic and prognostic techniques. This could suppose multiple advantages in front of the current methods regarding the management and clinical outcome of patients with TBI. ${ }^{3}$

Traumatic brain injury comprises a heterogeneous group of traumatic injuries, which can evolve progressively. According to the Glasgow Coma Scale (GCS), TBI is classified as mild, moderate, or severe. ${ }^{4}$ Once the primary lesion occurs, biochemical mechanisms are activated that promote the injury to states of greater severity, which is known as secondary injury. ${ }^{5}$ The primary lesion is evidenced by the appearance of neural injury and hemorrhages at different levels of the intracranial structures, which include subarachnoid hemorrhage $(\mathrm{SAH})$, subdural hematoma $(\mathrm{SDH})$, epidural hematoma $(\mathrm{EDH})$, and intracerebral hematoma $(\mathrm{ICH}) .{ }^{6}$ These lesions are frequently associated with disruption of the blood-brain barrier (BBB), which become permeable to molecules from nervous tissue to blood and cerebrospinal fluid (CSF), becoming potential biomarkers of brain injury, when it is not evident in the CT. ${ }^{7}$

Current neuromonitoring strategies in TBI include the use of neuroimaging such as computed tomography (CT), nuclear magnetic resonance (NMR), and bedside monitors such as transcranial Doppler (TCD), intracranial pressure (ICP), microdialysis, or brain tissue oxygen. These tools are routinely used for identifying and monitoring temporal trends of anatomical and physiological parameters associated with progressive neurological worsening and mortality. ${ }^{8}$ However, despite the availability of these tools, its remains problematic to correlate the changes detected with the level of secondary injury and predicting the clinical course in acute and in the long-term phase of the illness, given the heterogeneity of the TBI. Additionally, the aforementioned techniques imply high cost and often the mobilization and transfer of the patient. ${ }^{3}$

In this sense, the use of biomarkers represents a practical and cost-effective alternative to monitoring, especially in situations in which the diagnostic equipment, described above, is not available, such as centers in low- and middle-income countries (LMICs), or during the transfer of patients from remote locations to the specialist centers. The quantification of detectable biomarkers in the early phases after trauma would optimize the times for the timely implementation of specific therapies, becoming a tool for predicting neuroworsening in the acute phase of the illness.

The S-100B protein has been a widely studied candidate. $\mathrm{S}-100 \mathrm{~B}$ is a calcium-binding astrocytic protein, which is released just after impact on the skull, as a consequence of $B B B$, and
${ }^{1-3,7,8}$ Department of Medicine, Universidad del Norte, Barranquilla, Atlántico, Colombia

${ }^{4}$ Medicine Program, Universidad Metropolitana, Barranquilla, Atlántico, Colombia

5,6 Department of Medicinea, Universidad Metropolitana, Barranquilla, Atlántico, Colombia

Corresponding Author: Sanjuán H, Department of Medicine, Universidad del Norte, Barranquilla, Atlántico, Atlántico, Colombia, Phone: +57 53509509, e-mail: alexander.ciencia@gmail.com

How to cite this article: Sanjuán H, Cervera E, Macchia G, et al. Utility of S-100B as a Potential Tool for Neuromonitoring and Prediction of Neuroworsening in Acute Phase of Traumatic Brain Injury. Panam J Trauma Crit Care Emerg Surg 2020;9(2):105-113.

Source of support: Colciencias (contract 680-2014) and Univeridad del Norte (Cod: 2014-0019)

Conflict of interest: None

correlates very sensitively with tomographic findings such as brain contusion, $\mathrm{EDH}, \mathrm{SDH}$, and SAH, among others. ${ }^{9,10}$ However, S-100B is not released exclusively from the brain. Certain cells, such as adipocytes, epithelial, muscle, cardiac, skeletal cells, chondrocytes, and Langerhans cells are also the source of this protein, ${ }^{11,12}$ so high concentrations of S-100B have been identified in the blood of polytraumatized patients without apparent damage to the central nervous system. ${ }^{13-16}$

It has been documented that S-100B levels change early and quickly after a central nervous system-related injury. ${ }^{17}$ Astrocytes, for example, release the stored S100B in just 15 seconds. ${ }^{18}$ Once in blood, S-100B reaches significantly high concentrations if comparing it to the reference value $(0.1 \mathrm{ug} / \mathrm{L})$ in the absence of head trauma. ${ }^{19,20} \mathrm{~S}-100 \mathrm{~B}$ can be completely metabolized and excreted by the kidneys at the level of the proximal tubules; ${ }^{21}$ however, its plasma half-life is not known exactly, due to the interindividual variability among patients, the constant production and release $\mathrm{S}-100 \mathrm{~B}$ from the affected tissue, and the variation in the methodological approaches used. 17,20,22

Taking into account the release rate of $\mathrm{S}-100 \mathrm{~B}$ and the rate of renal elimination, some authors suggest that the half-life of this protein in patients with TBI is short, between 60 and 120 minutes, which suggests that the continuous elevation of the levels of this protein may be associated with brain injury. ${ }^{23,24}$ Although extracranial sources of S-100B may interfere with the evaluation of damage to the central nervous system, it must be taken into account that extracranial blood levels of S-100B are eliminated faster than central nervous system blood levels, as indicated in Figure $1 .{ }^{17,25-28}$ According to this, serum levels of S-100B at 12 hours' posttrauma could be considered a better indicator of postconcussion syndrome and neurological dysfunction in patients with mild TBI trauma. ${ }^{17,29}$ 
In fact, most of the published studies report that measurement of serum of S-100B in the context of mild TBI, as a predictor of CT findings, represents a valuable tool when establishing a criterion for indication of CT and to decide medical discharge. Likewise, several studies have reported that correlation of S-100B with the clinical course of the patient with severe TBI, thus showing it to be an excellent indicator of intracranial hypertension (ICH). However, there are few studies that report the impact of S-100B as a predictor of neurological deterioration in the acute phase of moderate TBI. In this review, we summarize the available evidence on the use of $\mathrm{S}-100 \mathrm{~B}$ in TBI of all severities, their clinical significance, and their prognostic value in the different post trauma stages (Fig. 1).

\section{Materials and Methods}

To obtain the information presented in this review, we used the Web of Science, PubMed, and Scopus scientific databases. The search period was from 2010 to 2020, using the following Boolean strings for all the databases: ((s100b[All Fields] OR S-100b[All Fields]) AND ("prognosis"[MeSH Terms] OR "prognosis"[All Fields])) AND ("brain injuries, traumatic"[MeSH Terms] OR ("brain"[All Fields] AND "injuries"[All Fields] AND "traumatic"[All Fields]) OR "traumatic brain injuries"[All Fields] OR ("traumatic"[All Fields] AND "brain"[All Fields] AND "injury"[All Fields]) OR "traumatic brain injury"[All Fields]) AND ("2010/01/01"[PDAT]: “2020/04/05"[PDAT]).

The downloaded database files were subsequently processed through frequency analysis in Microsoft Excel, and maps based on both bibliographic data and network data were generated using the VOSviewer software. The search gave us a total of 64 articles for PubMed, 1,567 for Web of Science, and 295 for Scopus, for a total of 1,926 articles in all databases. The proportion of MeSH keywords that meet a minimum threshold of occurrences of 5 and the whole number of MeSH keywords was 35/207 for PubMed, 203/1,831 for Web of Science, and 265/1,859 for Scopus. This information regarding the occurrence and total link strength (Fig. 2) was used to exclude most of the articles and to refine the search, and in addition, we used the following parameters to analyze and select the publications of S-100B over the past 10 years: number of references cited, number of references per article, number of pages per article, authors' performance, and journal publication patterns based on JCR impact factor and journal position by JCR categories. A total of 54 articles were selected to be included in this review.

\section{Review Results \\ Utility of S-100B as a Predictor of CT Findings in Mild TBI}

Almost $90 \%$ of patients with head injury who present to the hospital have mild TBI, which is defined by a 13-15 score on the GCS. ${ }^{30}$ Of this, only a few have a hemorrhagic lesion, which can be detected by further imaging techniques (CT scan). Still, utilizing imaging techniques in every single patient that comes to the ER does not only pose a burden to the finances of the hospital but, more importantly, also exposes the patients to unnecessary radiation. ${ }^{30-32}$ Serum S-100B levels have shown high sensibility and NPV (75-100\% and $90-100 \%$, respectively) for intracranial complications after mild head injury. ${ }^{33}$ Thus, proving a valuable tool to identify patients who truly merit further imaging studies owing to due to their risk of having a brain bleed.

It has been reported that measurement of S-100B can reduce the use of CT scans and hospital admissions by approximately $30 \% .^{30,31} \mathrm{~S}-100 \mathrm{~B}$ serum levels have already been used as a tool to determine which patients with mild TBI require a posterior CT scan to rule out tissue and hemorrhagic brain lesions. Using a cutoff value of $0.1 \mu \mathrm{g} / \mathrm{L}$, patients with mild TBI that had a value inferior to this were discharged; a 6-month follow-up period showed no readmissions, missed intracerebral bleeds, or deaths, ${ }^{31}$ showing the effectiveness of serum S-100B levels' NPV for predicting hemorrhagic lesions.

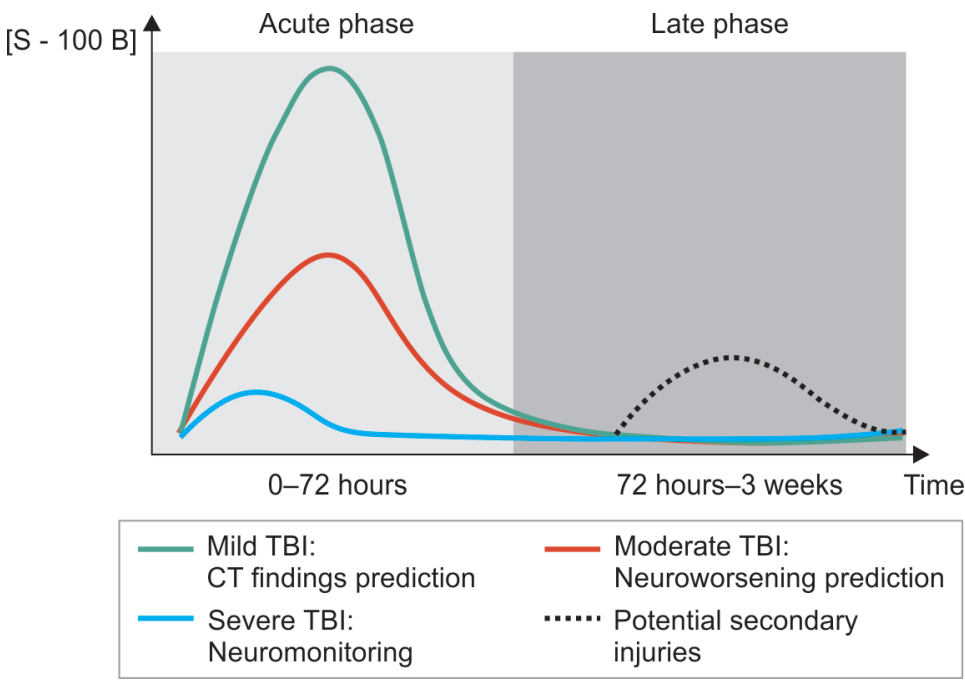

Fig. 1: Schematic representation of the clinical utility of S-100B according to the initial severity of the TBI, in acute and late phase. The panel of the left shows the early elevation of $\mathrm{S}-100 \mathrm{~B}$, the peaks are higher proportionally to the level of actual severity, defined by the process of neuroinflammation and secondary injury, however, the higher the peak, the greater the probability of neurodeterioration in the acute phase, which is particularly critical for moderate TBI, because the actual severity could be underestimated by GCS, while the levels of S-100B indicate that the trauma will actually behave like a severe TBI in the following hours. The panel on the right shows how the S-100B values tend to return to baseline values in the late stage, although the monitoring of their concentrations allows the detection of secondary peaks, which are related to secondary events of brain damage, serving as an indicator of response to treatment. Modified from Reference 12 


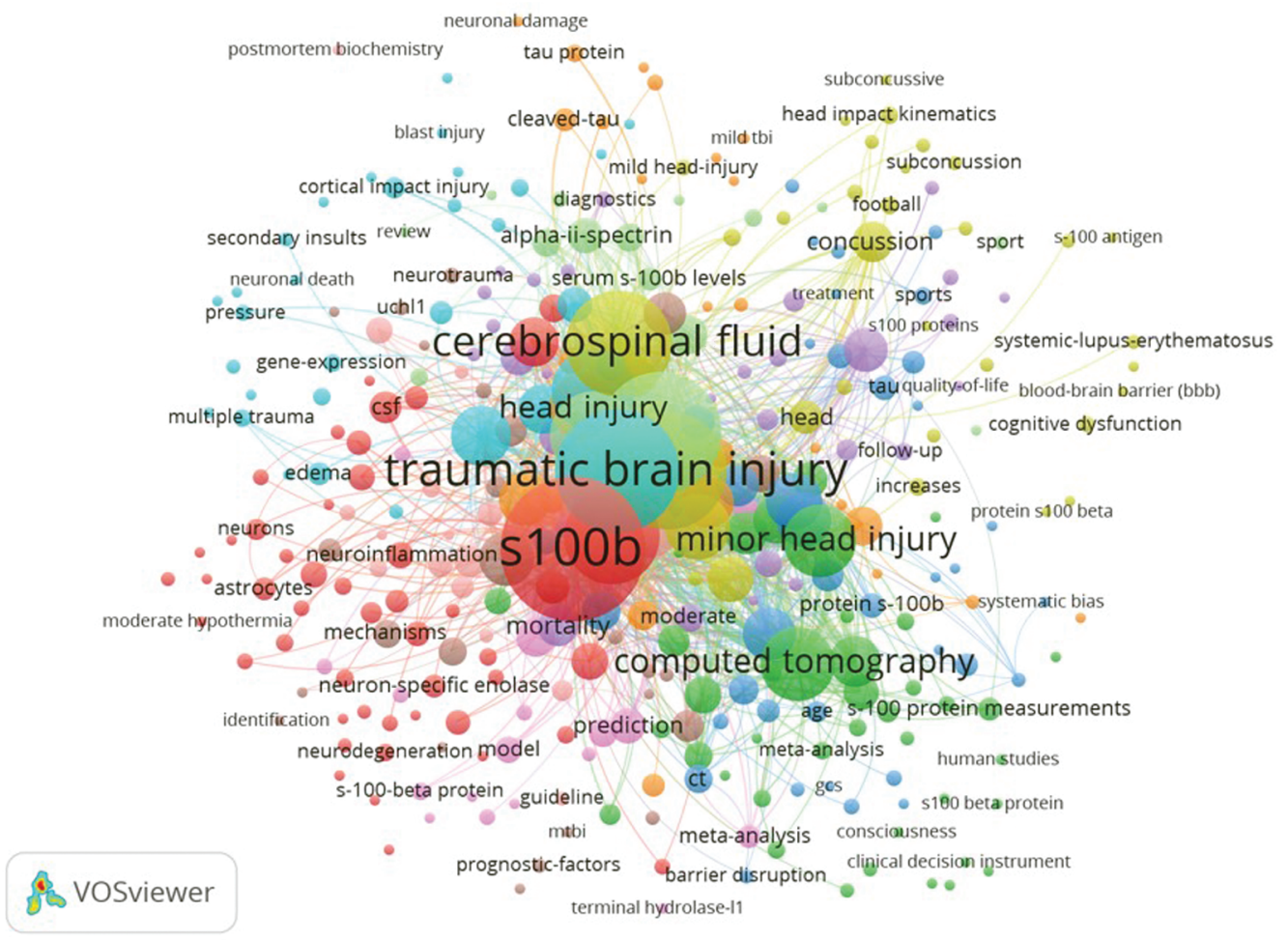

Fig. 2: Map of the MesH Keywords network showing the graphical link strength for frequencies $\geq 5$. The circle size represents the number of articles containing the keyword, and two different colors represent the presence of a significant connection between two groups of keywords

Several studies utilizing a cutoff value of $0.105 \mu \mathrm{g} / \mathrm{L}$ of serum S-100B also displayed the relevance of the NPV in abnormal CT scans (SDH, subarachnoid hematoma) in patients with mild TBI. They also presented a strong argument against the notion that S100B has no utility as a predictor of hemorrhagic lesions in the CT scans of patients who are receiving platelet aggregation (low-dose aspirin and clopidogrel) inhibitors or who are 65 years or older, thus refuting the Scandinavian guidelines for initial management of minimal, mild, and moderate head injuries in adults. ${ }^{30,32,34}$ These stated that all patients with the previously mentioned parameters required $C T$ scanning, thus implying the lack of predictive value for hemorrhagic lesions that S-100B had on patients who met this criteria. ${ }^{32,34}$

S-100B has utility for not only intraparenchymal hemorrhagic lesions but also those compromising the meninges. Patients with EDHs, which do not directly involve brain tissue damage but rather may lead to future tissue damage, have presented levels over 0.1 $\mu \mathrm{g} / \mathrm{L}$ of serum S-100B. This finding indicates that S-100B levels are associated with BBB disruption. Thus, they show great utility in predicting various types of intracranial bleeds of extracerebral origin. ${ }^{33}$

There is a relationship between the severity of the TBI and the amount of S-100B detected. ${ }^{35}$ Serum levels of S-100B in severe $\mathrm{TBI}$ that surpass the $7 \mu \mathrm{g} / \mathrm{L}$ have been shown to lead to a $100 \%$ patient mortality in 2 weeks, while levels over $0.2 \mu \mathrm{g} / \mathrm{L}$ increase the probability for a worse outcome and measurement after 24 hours can help predict brain death in such patients. ${ }^{30,36,37}$ All of this leading us to understand the relation between the presence and magnitude of the brain injury and the amount of serum S-100B.
To conclude, S-100B utility for predicting hemorrhagic lesions in patients with mild TBI relies mainly on its NPV, which, in most studies, ranges from 98 to $100 \% \cdot{ }^{30-34}$ Due to the fact that S-100B is released by other tissues besides neural tissue, its specificity for brain injury could be compromised if the patient also suffered injuries besides those in the CNS. ${ }^{33,38}$ Also, a positive S-100B, which usually ranges between 0.1 and $0.105 \mu \mathrm{g} / \mathrm{L}$, cannot be used to aid future clinical decision making, due to the consistently low PPV that it offers. ${ }^{30,32,39}$

\section{Utility of S-100B as a Neuromonitoring Tool in Severe TBI}

$\mathrm{S}-100 \mathrm{~B}$ is a sensitive biomarker for early prediction of $\mathrm{ICH}$ development and fatal outcome after TBI, so monitoring its serum concentrations could contribute to the timely identification of those patients at risk of secondary ICP elevation and increased mortality risk, allowing therapy to be conducted earlier in selected patients.

In this sense, Petzold et al. ${ }^{40}$ evaluated in a prospective cohort of 21 patients with TBI and 13 healthy controls, the ICP, GCS score, and pupillary reaction, on admission and in the following 6 days, together with the serum concentrations of S-100B. With a sensitivity of $100 \%$ and a specificity of $75-83 \%$, the concentrations of S-100B were significantly higher on admission $(p<0.05)$ and on day 1 ( $p$ $<0.01$ ), in patients with fatal outcome, reporting a mortality risk 8 times greater in those who presented high values of S-100B at admission, and 12 times higher when said elevation persisted on day 1 . These findings correlated with high values of ICP.

The subsequent serum values of $\mathrm{S}-100 \mathrm{~B}$ predicted the development of elevated ICP in patients with TBI $(p<0.01)$. Patients 
with high ICP on day 5 had 11 times more risk for a fatal outcome while those with high ICP on day 6 had a fatal outcome risk, which was 9 times greater. ${ }^{40}$ Olivecrona et al. report that the maximum intracranial pressure (ICPmax) and minimum cerebral perfusion pressure (CPPmin) are clearly correlated with S-100B levels. The correlation was significant for three types of measurements: the initial measurement, the maximum concentration measured in the first 5 days posttrauma, and the total release of the biomarker during the first 72 hours, calculated by the area under the curve. In general, the maximum concentrations $(r=0.69, p=0.001)$ and the total release $(r=0.68, p=0.0001)$ of S-100B correlated better with the ICPmax, compared to the initial measurement $(r=0.52$, $p=0.0005)$. These results were similar in relation to the CPPmin, and also in function of another biomarker, neuron-specific enolase (NSE). ${ }^{38}$ Table 1 summarizes main literature available that correlates S-100B with neuromonitoring techniques, such as ICP monitoring, and neuroworsening in moderate to severe TBI.

\section{Utility of S-100B as a Predictor of Neurological Worsening in the Acute Phase}

The use of S-100B protein as a tool in the diagnosis, monitoring, and prognosis of TBI has been discussed throughout this review. Still, one point in which studies are still needed is in this protein's ability to predict neuroworsening in early stages, in patients who have suffered a moderate TBI, due to the potential neurological deterioration and the need to implement aggressive management with endotracheal intubation and/or hyperosmolar therapy. The secondary lesions generated by the subsequent inflammatory process after the trauma can take hours to show clinical manifestations, happening when the injury is very extensive, thus worsening the patient's prognosis and increasing mortality before timely interventions can be made.

Andriessen et al. conducted a prospective cohort study with a sample of 508 patients. They found that of the 169 patients diagnosed as moderate at emergency department (ED) evaluation, $39(24 \%)$ deteriorated to a GCS less than or equal to 8 and remained unconscious for more than 6 hours, thus giving room to question the prognostic value of prehospital GCS scores. Interestingly, it can be observed that at least $15 \%$ of their cohort's diagnosis changed from the scene of the injury to the ED. Researchers concluded that combining information from both the scene of the injury and ED admission may have additional value for injury severity classification and outcome prediction than just using the GCS. Also, they found that among patients that had 6 or more hours of impaired consciousness, positive CT findings were present in $86 \%$ of patients with severe TBI and $76 \%$ in patients with moderate TBI. In patients with severe and moderate TBI and impaired consciousness for less than 6 hours, CT findings were 52 and $50 \%$, respectively. This shows that a relatively long time is required for intracranial lesions to appear on CT scan in both severe and moderate $\mathrm{TBI} .{ }^{41}$ If relevant therapeutic actions had been performed in a timely manner, $26 \%$ of the CT findings could have been avoided. They also found three patients with an ED admission diagnosis of moderate TBI who were intubated before GCS evaluation and 77 patients (15\%) with a change in injury severity category due to fluctuations in the GCS. This study reports a hospital mortality rate in those patients with mild/moderate TBI that deteriorated to severe TBI (M-S, 14\%), and those with mild/moderate $\mathrm{TBI}$ at the injury scene and moderate TBI at the ED (M-M, 15\%). ${ }^{41}$

In another study, Thelin et al. performed a database study of S-100B and NSE levels collected prospectively from patients admitted to the NICU at Karolinska University Hospital from January 1,2005 , to December 31, 2013. With a sample of 417 patients, they found that patients with favorable outcome have low and rapidly decreasing levels of S-100B and NSE, while S-100B and NSE levels in patients with an unfavorable outcome remain elevated during a longer period of time, presumably indicating an ongoing cerebral injury. ${ }^{12}$

Bouzat et al. carried out a prospective cohort study, with a sample of 67 patients; its objective was to test whether the determination of the serum protein S-100B could predict a secondary neurological deterioration. They defined secondary neurological impairment as a decrease in initial GCS of two points or more, or any treatment for neurological worsening. They identified nine patients with secondary neurological deterioration after trauma. No differences were found in the serum levels of S-100B protein between these patients and those without neurological aggravation ( $n=58$ patients): $0.93 \mu \mathrm{g} / \mathrm{L}(0.14-4.85)$ vs $0.39 \mu \mathrm{g} / \mathrm{L}$ (0.04-6.40), respectively. They concluded that the measurement of serum protein S-100B at the time of admission was unable to predict patients with risk of neurological deterioration after a mild or moderate TBI. They also remarked that extracranial lesions can increase serum S-100 protein levels limiting the usefulness of this quantification in the prediction of neuroworsening. ${ }^{42}$

Korfias et al. designed a prospective observational study in a neurosurgical intensive care unit with the aim of examining the relationship between serum S-100B concentrations and injury severity, clinical course, survival, and treatment efficacy after severe TBI with a sample of 102 adult patients with severe TBI, admitted between June 2001 and November 2003. They defined neurological change as improvement or worsening in GCS score, alteration of the pupillary reaction, and presentation of new neurological signs (difficulty in speech-aphasia or motion-hemiparesis, or development of seizures). They found a statistically significant correlation between serum S-100B course and neurological improvement $(n=21)$ or deterioration $(n=29)$ during the 1st week of hospitalization ( $p=0.0002$ and $p=0.001$, Wilcoxon signedrank test). Their findings were related to others in the literature that showed that high serum levels of S-100B are well correlated with primary damage, secondary deterioration, and unfavorable outcome in severe TBI and that the quantification of S-100B is a promising serum marker for assessing the extent of primary injury and the time course of secondary damage. ${ }^{43}$

\section{Discussion}

Monitoring ICP remains the main strategy of neuromonitoring in the management of patients with severe $\mathrm{TBI}^{44}$ Chesnut et al. demonstrated that the treatment of severe TBI based on controlled maintenance of ICP $\leq 20 \mathrm{~mm} \mathrm{Hg}$ is not superior to image-based management and clinical examination. In this multicenter controlled trial, conducted in Ecuador and Bolivia, 324 patients with severe TBI treated in the ICU were randomly assigned to one of two groups. In one of the groups, management was based on intraparenchymal monitoring of ICP, while in the other, it was based on imaging and clinical data. Survival and functional status were evaluated at 3 and 6 months and the neuropsychological state at 6 months, showing no evidence of significant difference in terms of mortality $(p=0.60)$ and days of ICU stay $(p=0.25)$. However, it was found that the duration of specific treatments for ICH was lower in the group with ICP monitoring $(p=0.002)$. Complications and adverse events were similarly distributed in both groups. ${ }^{45}$ 
Table 1: Main literature available, where S-100B levels have been correlated with neuromonitoring techniques, such as ICP monitoring, and neuroworsening in moderate-to-severe TBI

\begin{tabular}{|c|c|c|c|}
\hline Reference & Type of study & $n$ & Findings \\
\hline Petzold et al. ${ }^{40}$ & $\begin{array}{l}\text { Prospective } \\
\text { cohort }\end{array}$ & 34 & $\begin{array}{l}\text { S-100B predicted the development of elevated ICP in patients with TBI }(p<0.01) \text {. The } \\
\text { average S-100B level measured at admission was } 1 \pm 3 \mathrm{pg} / \mathrm{mL} \text { in the control group, and in } \\
\text { patients with TBI it was } 37 \pm 30 \text { and } 110 \pm 50 \mathrm{pg} / \mathrm{mL} \text { in those who survived and those who } \\
\text { died, respectively. }\end{array}$ \\
\hline Olivecrona et al. ${ }^{38}$ & $\begin{array}{l}\text { Prospective } \\
\text { cohort }\end{array}$ & 48 & $\begin{array}{l}\text { In patients with severe TBI, best correlation of ICP with S-100B: maximum concentrations } \\
(r=0.69, p=0.001) \text { and } \mathrm{S}-100 \mathrm{~B} \text { total release }(r=0.68, p=0.0001) \text {. Initial S-100B concentra- } \\
\text { tions, at } 72 \text { hours, maximum and total release were } 1.04 \pm 0.21 ; 0.40 \pm 0.04 ; 1.37 \pm 0.45 ; \text { and } \\
4.09 \pm 1.38 \mu \mathrm{g} / \mathrm{L} \text {, respectively. }\end{array}$ \\
\hline Hendoui et al. ${ }^{48}$ & Clinical trial & 33 & $\begin{array}{l}\text { Negative correlation between serum S-100B level and GCS on 1st }(r=-0.401, p=0.021) \text { and } \\
\text { 3rd days }(r=-0.469, p=0.006) \text {. }\end{array}$ \\
\hline Shakeri et al. ${ }^{49}$ & Cross-sectional & 72 & $\begin{array}{l}\text { Significant negative correlation between final GCS and protein S-100B level at first } \\
(p=0.027), 48 \text { hours later }(p<0.0005) \text {, and final measurement }(p<0.0005) \text {. }\end{array}$ \\
\hline \multirow[t]{4}{*}{$\begin{array}{l}\text { Andriessen } \\
\text { et al. }{ }^{41}\end{array}$} & \multirow[t]{4}{*}{$\begin{array}{l}\text { Prospective } \\
\text { cohort }\end{array}$} & \multirow[t]{4}{*}{508} & $\begin{array}{l}\text { Total } 169 \text { patients diagnosed as moderate at emergency department (ED) evaluation, } 39 \\
(24 \%) \text { deteriorated to a GCS less than or equal to } 8 \text { and remained unconscious for }>6 \text { hours. }\end{array}$ \\
\hline & & & At least $15 \%$ of their cohort, diagnosis changed between injury scene and ED. \\
\hline & & & $\begin{array}{l}\text { Total } 77 \text { patients (15\%), with change in injury severity category due to fluctuations in the } \\
\text { GCS. }\end{array}$ \\
\hline & & & Hospital mortality rates in patients with mild/moderate TBI deteriorating to severe TBI (14\%). \\
\hline Thelin et al. ${ }^{50}$ & Database study & 417 & $\begin{array}{l}\text { High S-100B and NSE levels correlate with poorer long-term health conditions. Being the lev- } \\
\text { els of S-100B those that exhibit a better discrimination between different groups according } \\
\text { to the Glasgow results scale (GOS): GOS1 = dead, GOS2 = vegetative state, GOS3 = severe, } \\
\text { dependent state, GOS4 = moderately recovered, independent state, and GOS5 = good } \\
\text { recovery. Especially when measured between } 24 \text { and } 36 \text { hours after trauma. The NSE levels } \\
\text { only discriminated GOS1 from the rest of the groups. }\end{array}$ \\
\hline \multirow[t]{2}{*}{ Bouzat et al. ${ }^{42}$} & \multirow[t]{2}{*}{$\begin{array}{l}\text { Prospective } \\
\text { cohort }\end{array}$} & \multirow[t]{2}{*}{67} & $\begin{array}{l}\text { Nine patients with secondary neurological impairment after trauma were identified. No } \\
\text { differences were found in the serum levels of S-100B protein between these patients and } \\
\text { those without neurological aggravation ( } n=58 \text { patients): } 0.93 \mathrm{mg} / \mathrm{L}(0.14-4.85) \mathrm{vs} 0.39 \mathrm{mg} / \mathrm{L} \\
(0.04-6.40) \text {, respectively. }\end{array}$ \\
\hline & & & $\begin{array}{l}\text { S-100B at the time of admission did not allow to predict patients with risk of neurological } \\
\text { deterioration after a mild or moderate traumatic brain injury. }\end{array}$ \\
\hline \multirow[t]{3}{*}{ Korfias et al. ${ }^{43}$} & \multirow[t]{3}{*}{$\begin{array}{l}\text { Prospective } \\
\text { cohort }\end{array}$} & \multirow[t]{3}{*}{102} & $\begin{array}{l}\text { To assess if the S-100B protein is a promising marker of injury severity and outcome after } \\
\text { head injury in adult patients, serum S-100B levels were measured on admission and every } 24 \\
\text { hours thereafter for a maximum of } 7 \text { days. }\end{array}$ \\
\hline & & & $\begin{array}{l}\text { Initial S-100B values ranged from } 0.15 \text { to } 32.9 \mu \mathrm{g} / \mathrm{L} \text { (mean } 2.1 \text {; median } 1.72 \mu \mathrm{g} / \mathrm{L} \text { ); the highest } \\
\text { observed value during the first } 7 \text { days of hospitalization was } 48.6 \mu \mathrm{g} / \mathrm{L} \text {. A significant relation- } \\
\text { ship was found between initial serum S-100B levels and CT Marshall classification }(p=0.047 \text { ). } \\
\text { Subjects with Marshall VI grade (nonevacuated lesions }>25 \mathrm{~mL} \text { ) presented with statistically } \\
\text { higher initial serum S-100B levels than those with Marshall grades I or II ( } p=0.032 \text { ). }\end{array}$ \\
\hline & & & $\begin{array}{l}\text { Cox's proportional hazard regression analysis shows a threefold increased probability of } \\
\text { death within } 1 \text { month when initial serum S-100B levels were } 1-1.99 \text { vs } 2 \mu \mathrm{g} / \mathrm{L} \text { or higher. }\end{array}$ \\
\hline \multirow[t]{3}{*}{ Doha et al. ${ }^{51}$} & \multirow[t]{3}{*}{$\begin{array}{l}\text { Prospective } \\
\text { cohort }\end{array}$} & \multirow[t]{3}{*}{40} & $\begin{array}{l}\text { The patients were divided into two equal groups. Group I: patients with traumatic head } \\
\text { injury, Il: patients with trauma rather than head trauma. }\end{array}$ \\
\hline & & & $\begin{array}{l}\text { Significant difference between the results of S-100B in group I and group II was detected } \\
(p<0.001) \text {, with higher results of S-100B in TBI patients. Significant difference between the } \\
\text { results of S-100B in survival and nonsurvival for patients in group I was detected ( } p=0.002) \text {, } \\
\text { with higher results of S-100B in nonsurvival patients. }\end{array}$ \\
\hline & & & $\begin{array}{l}\text { This research also showed a statistically significant difference in Spearman's correlation } \\
\text { between S-100B protein and GCS }(p<0.05) \text {. }\end{array}$ \\
\hline $\begin{array}{l}\text { Park and } \\
\text { Hwang }^{52}\end{array}$ & $\begin{array}{l}\text { Prospective } \\
\text { cohort }\end{array}$ & 15 & $\begin{array}{l}\text { Total } 15 \text { pediatric patients ( } 18 \text { years old) with TBI were enrolled in this study. Median serum } \\
\text { concentrations of S-100B, NSE, and IL- } 6 \text { at admission were } 178.12 \mathrm{pg} / \mathrm{mL}, 16.54 \mathrm{ng} / \mathrm{mL} \text {, and } \\
15.48 \mathrm{pg} / \mathrm{mL} \text {. The serum S-100B and NSE level both at admission and } 1 \text { week after trauma } \\
\text { was significantly higher in the poor GCS group than in the good GCS group }(p<0.05) \text {. In } \\
\text { contrast, the serum IL- } 6 \text { level in the poor GCS group was slightly lower than in the good GCS } \\
\text { group at admission and higher than the good GCS group I week after the trauma. However, } \\
\text { this difference was not significant ( } p=0.053) \text {. }\end{array}$ \\
\hline
\end{tabular}


Contd...

\begin{tabular}{|c|c|c|c|}
\hline Reference & Type of study & $n$ & Findings \\
\hline Yalcin et al..$^{53}$ & $\begin{array}{l}\text { Prospective } \\
\text { cohort }\end{array}$ & 58 & $\begin{array}{l}\text { Total } 58 \text { adult patients (>18 years) were admitted. Serum S-100B levels were measured pro- } \\
\text { spectively and compared according to clinical findings and outcomes of the patients. Accord- } \\
\text { ing to the ROC analysis, cut-off values for S-100B for the differential diagnosis of patients with } \\
\text { and without brain damage were found to be } 785.944 \mathrm{ng} / \mathrm{mL} \text {. The GCS score of the patients } \\
\text { varied between } 6 \text { and } 15 \text {. There was a statistical significance between the patients with and } \\
\text { without TBI according to GCS. In addition, a negative correlation between GCS and S-100B } \\
\text { levels was determined (S100B rho: }-0.64 \text { ). }\end{array}$ \\
\hline \multirow[t]{2}{*}{ Vos et al. ${ }^{54}$} & $\begin{array}{l}\text { Prospective } \\
\text { cohort }\end{array}$ & 79 & $\begin{array}{l}\text { In } 79 \text { patients with TBI (GCS } \leq 12) \text {, serum, taken at hospital admission, was analyzed for GFAP } \\
\text { and S-100B. }\end{array}$ \\
\hline & & & $\begin{array}{l}\text { In patients who died compared with alive patients, median serum levels were increased: } \\
\text { GFAP } 33.4 \text {-fold and S-100B } 2.1 \text {-fold. In unfavorable compared with favorable outcome, GFAP } \\
\text { was increased 19.8-fold and S-100B } 2.1 \text {-fold. Multivariable analysis showed that models } \\
\text { containing mass lesion, pupils, GFAP, and S-100B were the strongest in predicting death and } \\
\text { unfavorable outcome. S-100B was the strongest single predictor of unfavorable outcome } \\
\text { with } 100 \% \text { discrimination. }\end{array}$ \\
\hline
\end{tabular}

The results of this trial, and the fact that ICP monitoring is infrequent in low- and middle-income countries (LMICs), have motivated new research that seeks to define alternative methods that allow patients to follow-up with severe TBI without ICP monitoring. By the time this review was written, the Global Neurotrauma Research Group was developing the ConsensusBased Guidelines (CBG) project in Latin America for the creation and validation of guidelines for the treatment of severe TBI in the absence of ICP monitoring. Partial results of this initiative show the analysis of different predictors using a proportional multivariate probability model in 550 patients. At 6 months' posttrauma, 37\% of the patients had died, while $44 \%$ reached a GOS-E of 5-8. A high score on the motor Glasgow ([OR 1.41], Cl 1.23-1.61) and the finding of $\mathrm{EDH}$ ([OR 1.83], $\mathrm{Cl}$ 1.17-2.86) were significant predictors of a high score in GOS-E, while advanced age ([OR 0.65], Cl 0.57-0.73) and the effacement of cisterns $(p<0.001)$ were associated with a low GOS-E score. Strikingly, the site where the study was conducted $(p<0.001)$ and race $(p=0.004)$ were associated with the result in a significant way, surpassing even the clinical variables such as hypotension and pupillary examination, suggesting an important predictive role of sociodemographic factors, although additional research is required to understand these associations. ${ }^{46}$

The only clinical protocol that has been prospectively tested in a clinical trial for the treatment of TBI without control of ICP is the Benchmark Evidence from South American Trials: Treatment of Intracranial Pressure (BEST TRIP), which used the imaging and clinical examination (ICE) algorithm, reporting a favorable GOS score at 6 months (39\%) and a mortality rate (41\%) without significant differences compared to the group with treatment based on ICP monitoring. This study strongly supports the idea that the aggressive and diligent treatment of $\mathrm{ICH}$, suspected or monitored, is probably a critical component for the successful management of TBl; so, the aggressiveness of the treatment should not be diminished in the absence of ICP monitoring. The authors also highlight the need for this protocol to be modified to increase efficiency, while including other monitoring tools. ${ }^{47}$

In general, studies in relation to monitoring and predictive models in TBI, in the LMIC, show the need to incorporate new strategies to improve the sensitivity and reduce the window of time in the detection of the neuroworsening processes, imageneological and clinically evident, and in that way to be able to implement specific therapies in a timely manner. Serum biomarkers have been one of the main candidates for this purpose, with S-100B being one of the most studied.

The variations observed in the different studies in relation to the serum levels of S-100B and its association with the ICP, the findings in the $C T$, the clinical outcome, and its prognostic value may be due to methodological limitations, such as blood sampling, ICP measuring technique, and CT scan evaluation method. Additionally, it is likely that some treatment strategies may affect S-100B levels, ${ }^{38}$ an aspect barely discussed in the literature. Treatments that could affect the kinetics of S-100B include sedatives, vasopressors, aggressive fluid replacement, and hyperosmolar therapy. In the latter case, it has been reported that mannitol therapy would increase serum levels of S-100B, since its hyperosmotic action increases the permeability of the BBB. ${ }^{22}$

The usefulness of S-100B in TBI has been studied mainly to support the need to perform a CT in mild TBI and to monitor patients with moderate to severe $\mathrm{TBI}$, as a predictor of outcome and elevation of the ICP, as well as a tool for monitoring the response to treatment. ${ }^{12}$ However, despite the available evidence as a valuable tool, S-100B is rarely used among clinicians who manage patients with TBI and, to our knowledge, only S-100B has been routinely included in the Scandinavian guidelines for the management of TBI. It is possible that this is due to the fact that published studies show a tendency toward low S-100B specificity, due to the extracranial sources of S-100B in the polytraumatized patient. Therefore, in order to increase the usefulness of S-100B, and extend its use, it is necessary to improve the understanding of the kinetics of this biomarker, so as to discriminate the origin of the ultra-early and late levels of S-100B, in addition to a clearer differentiation in relation to the extracerebral levels of the marker, as well as defining the reference values related to age for the pediatric population.

Future work should also compare S-100B in the context of multivariate analysis, in such a way that other known predictors are included, such as established prognostication models like IMPACT (International Mission for Prognosis and Analysis of Clinical Trials in TBI) or BEST TRIP variables.

\section{ConClusion}

Clinical data and neuroimaging have been used as prognostic tools, in the detection of findings associated with progressive neuroworsening and mortality. However, given the heterogeneity 
of the $\mathrm{TBI}$, there are still difficulties to correlate the findings with secondary injury, and to predict the clinical evolution in the acute phase and in the long-term. Additionally, CT and MRI imply high cost and the mobilization and transfer of the patient.

Serum S-100B is a useful marker of brain damage in TBI. Its usefulness has been studied mainly as a support to define the need to perform a CT scan in mild TBI, and to monitor patients with moderate-to-severe TBI, in order to predict the outcome and validate the response to treatment. This review highlights S-100B as a versatile marker whose clinical significance depends on the severity of the trauma. In this way, S-100B would be a potential predictor of neuroworsening in the acute phase in moderate $\mathrm{TBI}$; however, more studies specifically focused on this subgroup are required.

\section{Clinical Significance}

We consider that despite its valuable utility as a predictor of positive $\mathrm{CT}$ in mild TBI, and as a tool for neuromonitoring in established severe $\mathrm{TBI}$, the greater utility of $\mathrm{S}-100 \mathrm{~B}$ could be as a predictor of neuroworsening in the acute phase in the moderate TBI, due to the great impact on early mortality that would cause the timely implementation of specific therapies.

\section{ACKNOWLedgments}

We thank to Colciencias (contract 680-2014). and Universidad del Norte (Cod: 2014-0019) for the financial support of the project in which this paper is involved.

\section{References}

1. Strimbu K, Tavel JA. What are biomarkers? Curr Opin HIV AIDS [Internet] 2010;5(6):463-466. DOI: 10.1097/COH.0b013e32833ed177. Available from: http://www.ncbi.nlm.nih.gov/pubmed/20978388.

2. Chau $\mathrm{CH}$, Rixe $\mathrm{O}, \mathrm{McLeod} \mathrm{H}$, et al. Validation of analytic methods for biomarkers used in drug development. Clin Cancer Res [Internet] 2008;14(19):5967-5976. DOI: 10.1158/1078-0432.CCR-07-4535. Available from: http://www.ncbi.nlm.nih.gov/pubmed/18829475.

3. Dadas A, Washington J, Diaz-Arrastia R, et al. Neuropsychiatric Disease and Treatment Dovepress Biomarkers in traumatic brain injury (TBi): a review. Neuropsychiatr Dis Treat. 2018. 2989-3000. DOI: 10.2147/NDT.S125620.

4. Matis G, Birbilis T. The Glasgow coma scale-a brief review. Past, Present, Future Acta Neurol Belg [Internet] 2008;108(3):75-89. Available from: http://www.ncbi.nlm.nih.gov/pubmed/19115670.

5. Maas AIR, Menon DK, Adelson PD, et al. Traumatic brain injury: integrated approaches to improve prevention, clinical care, and research. Lancet Neurol [Internet] 2017;16(12):987-1048. DOI: 10.1016/ S1474-4422(17)30371-X. Available from: http://www.ncbi.nlm.nih. gov/pubmed/29122524.

6. Haacke EM, Duhaime AC, Gean AD, et al. Common data elements in radiologic imaging of traumatic brain injury. J Magn Reson Imaging [Internet] 2010;32(3):516-543. DOI: 10.1002/jmri.22259. Available from: http://www.ncbi.nlm.nih.gov/pubmed/20815050.

7. Rodríguez A, Cervera E, Valencia G, et al. Revisión de tema: Biomarcadores neuronales y gliales como estrategia de clasificación cuantitativa de la severidad del trauma craneoencefálico. Rev Científica Salud Uninorte 2016;32(2):302-318. DOI: 10.14482/ sun.32.2.8835.

8. Kulbe JR, Geddes JW. Current status of fluid biomarkers in mild traumatic brain injury. Exp Neurol [Internet] 2016;275(Pt 3 03):334352. DOI: 10.1016/j.expneurol.2015.05.004. Available from: http:// www.ncbi.nlm.nih.gov/pubmed/25981889.

9. Undén J, Bellner J, Astrand R, et al. Serum S100B levels in patients with epidural haematomas. Br J Neurosurg [Internet] 2005;19(1):43-45.
DOI: 10.1080/02688690500089381. Available from: http://www.ncbi. nlm.nih.gov/pubmed/16147582.

10. Romner $B$, Ingebrigtsen $T$, Kongstad $P$, et al. Traumatic brain damage: serum S-100 protein measurements related to neuroradiological findings. J Neurotrauma 2000;17(8):641-647. DOI: 10.1089/089771500415391.

11. Haimoto H, Hosoda S, Kato K. Differential distribution of immunoreactive S100-alpha and S100-beta proteins in normal non nervous human tissues. Lab Invest 1987;57(5):489-498.

12. Thelin EP, Nelson DW, Bellander B-M. A review of the clinical utility of serum S100B protein levels in the assessment of traumatic brain injury. Acta Neurochir (Wien) 2017;159(2):209-225. DOI: 10.1007/ s00701-016-3046-3.

13. Anderson RE, Hansson LO, Nilsson O, et al. High serum S100B levels for trauma patients without head injuries. Neurosurgery 2001;48(6):12551258. DOI: 10.1097/00006123-200106000-00012; discussion 1258-60.

14. Pfortmueller CA, Drexel C, Krähenmann-Müller S, et al. S-100 B concentrations are a predictor of decreased survival in patients with major trauma, independently of head injury Kobeissy $\mathrm{FH}$, ed. PLoS One [Internet] 2016;11(3):e0152822. DOI: 10.1371/journal. pone.0152822. Available from: http://www.ncbi.nlm.nih.gov/ pubmed/27031106.

15. Routsi C, Stamataki E, Nanas $\mathrm{S}$, et al. Increased levels of serum S100b protein in critically ill patients without brain injury. Shock [Internet] 2006;26(1):20-24. DOI: 10.1097/01.shk.0000209546.06801. d7. Available from: http://www.ncbi.nlm.nih.gov/pubmed/16783193.

16. Undén J, Bellner J, Eneroth $M$, et al. Raised serum S100B levels after acute bone fractures without cerebral injury. J Trauma [Internet] 2005;58(1):59-61. DOI: 10.1097/01.ta.0000130613.35877.75. Available from: http://www.ncbi.nlm.nih.gov/pubmed/15674151.

17. Ercole A, Thelin EP, Holst A, et al. Kinetic modelling of serum S100b after traumatic brain injury. BMC Neurol [Internet] 2016;16(1):93. DOI: 10.1186/s12883-016-0614-3. Available from: http://www.ncbi.nlm.nih. gov/pubmed/27315805.

18. Willoughby KA, Kleindienst A, Müller C, et al. S100B protein is released by in vitro trauma and reduces delayed neuronal injury. J Neurochem [Internet] 2004;91(6):1284-1291. DOI: 10.1111/j.14714159.2004.02812.x. Available from: http://www.ncbi.nlm.nih.gov/ pubmed/15584905.

19. Pandor A, Goodacre S, Harnan S, et al. Diagnostic management strategies for adults and children with minor head injury: a systematic review and an economic evaluation. Health Technol Assess (Rockv) [Internet] 2011;15(27):1-202. DOI: 10.3310/hta15270. Available from: http://www.ncbi.nlm.nih.gov/pubmed/21806873.

20. Schulte S, Podlog LW, Hamson-Utley JJ, et al. A systematic review of the biomarker S100B: implications for sport-related concussion management. J Athl Train [Internet] 2014;49(6):830-850. DOI: 10.4085/1062-6050-49.3.33. Available from: http://www.ncbi.nlm. nih.gov/pubmed/25299445.

21. Usui A, Kato K, Abe T, et al. S-100ao protein in blood and urine during open-heart surgery. Clin Chem [Internet] 1989;35(9):1942-1944. DOI: 10.1093/clinchem/35.9.1942. Available from: http://www.ncbi.nlm. nih.gov/pubmed/2776321.

22. Kapural M, Krizanac-Bengez L, Barnett G, et al. Serum S-100 beta as a possible marker of blood-brain barrier disruption. Brain Res [Internet] 2002;940(1-2):102-104. DOI: 10.1016/s0006-8993(02)025866. Available from: http://www.ncbi.nlm.nih.gov/pubmed/12020881.

23. Ingebrigtsen $T$, Romner B. Biochemical serum markers of traumatic brain injury. J Trauma [Internet] 2002;52(4):798-808. DOI: 10.1097/00005373-200204000-00038. Available from: http://www. ncbi.nlm.nih.gov/pubmed/11956409.

24. Jackson RGM, Samra GS, Radcliffe J, et al. The early fall in levels of S-100 $\beta$ in traumatic brain injury. Clin Chem Lab Med [Internet] 2000;38(11):1165-1167. DOI: 10.1515/CCLM.2000.179. Available from: http://www.ncbi.nlm.nih.gov/pubmed/11156351.

25. da Rocha AB, Schneider RF, de Freitas GR, et al. Role of serum S100B as a predictive marker of fatal outcome following isolated severe 
head injury or multitrauma in males. Clin Chem Lab Med [Internet] 2006;44(10):1234-1242. DOI: 10.1515/CCLM.2006.218. Available from: http://www.ncbi.nlm.nih.gov/pubmed/17032136.

26. Savola O, Pyhtinen J, Leino TK, et al. Effects of head and extracranial injuries on serum protein S100B levels in trauma patients. 2004;56(6):1229-1234. DOI: 10.1097/01.ta.0000096644.08735.72; discussion 1234. Available from: http://www.ncbi.nlm.nih.gov/ pubmed/15211130.

27. Pham N, Fazio V, Cucullo L, et al. Extracranial sources of S100B do not affect serum levels. PLoS One [Internet] 2010;5(9). DOI: 10.1371/ journal.pone.0012691. Available from: http://www.ncbi.nlm.nih.gov/ pubmed/20844757.

28. Thelin EP, Zibung E, Riddez L, et al. Assessing bicycle-related trauma using the biomarker $\mathrm{S} 100 \mathrm{~B}$ reveals a correlation with total injury severity. Eur J Trauma Emerg Surg [Internet] 2016;42(5):617-625. DOI: 10.1007/s00068-015-0583-z. Available from: http://www.ncbi.nlm.nih. gov/pubmed/26490563.

29. Thelin EP, Johannesson L, Nelson D, et al. S100B is an important outcome predictor in traumatic brain injury. J Neurotrauma [Internet] 2013;30(7):519-528. Available from: http://www.liebertpub.com/ doi/10.1089/neu.2012.2553.

30. Thaler HW, Schmidsfeld J, Pusch M, et al. Evaluation of S100B in the diagnosis of suspected intracranial hemorrhage after minor head injury in patients who are receiving platelet aggregation inhibitors and in patients 65 years of age and older. J Neurosurg 2015;123(5):1202-1208. DOI: 10.3171/2014.12.JNS142276.

31. Ananthaharan A, Kravdal G, Straume-Naesheim TM. Utility and effectiveness of the Scandinavian guidelines to exclude computerized tomography Scanning in mild traumatic brain injury - a Prospective cohort study. BMC Emerg Med 2018;18(1):44. DOI: 10.1186/s12873-018-0193-2.

32. Undén J, Ingebrigtsen T, Romner B. (SNC) the SNC. scandinavian guidelines for initial management of minimal, mild and moderate head injuries in aDULTS: AN EVIDENCE AND CONSENSUS-BASED UPDATE. BMC Med [Internet] 2013;11(1):50. Available from: https:// doi.org/10.1186/1741-7015-11-50.

33. Unden J, Romner B. Can low serum levels of S100B predict normal CT findings after minor head injury in adults?: an evidence-based review and meta-analysis. J Head Trauma Rehabil 2010;25(4):228-240. DOI: 10.1097/HTR.0b013e3181e57e22.

34. David A, Mari C, Vignaud F, et al. Evaluation of S100B blood level as a biomarker to avoid computed tomography in patients with mild head trauma under antithrombotic medication. Diagn Interv Imaging 2017;98(7-8):551-556. DOI: 10.1016/j.diii.2017.03.010.

35. Aydin I, Algin A, Poyraz MK, et al. Diagnostic value of serum glial fibrillary acidic protein and S100B serum levels in emergency medicine patients with traumatic versus nontraumatic intracerebral hemorrhage. Niger J Clin Pract 2018;21(12):1645-1650. DOI: 10.4103/ njcp.njcp_431_17.

36. Kellermann I, Kleindienst A, Hore N, et al. Early CSF and serum S100B concentrations for outcome prediction in traumatic brain injury and subarachnoid hemorrhage. Clin Neurol Neurosurg 2016;145:79-83. DOI: 10.1016/j.clineuro.2016.04.005.

37. Egea-Guerrero JJ, Murillo-Cabezas F, Gordillo-Escobar E, et al. S100B protein may detect brain death development after severe traumatic brain injury. J Neurotrauma 2013;30(20):1762-1769. DOI: 10.1089/ neu.2012.2606.

38. Olivecrona Z, Bobinski L, Koskinen L-OD. Association of ICP, CPP, CT findings and S-100B and NSE in severe traumatic head injury. prognostic value of the biomarkers. Brain Inj [Internet] 2015;29(4):446-454. DOI: 10.3109/02699052.2014.989403.
39. Abbasi M, Sajjadi M, Fathi M, et al. Serum S100B protein as an outcome prediction tool in emergency department patients with traumatic brain injury. Turkish J Emerg Med [Internet] 2016;14(4):147-152. DOI: 10.5505/1304.7361.2014.74317. Available from: https://www.ncbi.nlm. nih.gov/pubmed/27437512.

40. Petzold A, Green AJE, Keir G, et al. Role of serum S100B as an early predictor of high intracranial pressure and mortality in brain injury: a pilot study. Crit Care Med 2002;30(12):2705-2710. DOI: 10.1097/00003246-200212000-00015.

41. Andriessen TMJC, Horn J, Franschman G, et al. Epidemiology, severity classification, and outcome of moderate and severe traumatic brain injury: A prospective multicenter study. J Neurotrauma 2011;28(10):2019-2031. DOI: 10.1089/neu.2011.2034.

42. Bouzat P, Francony G, Declety $\mathrm{P}$, et al. Can serum protein $\mathrm{S} 100$ beta predict neurological deterioration after moderate or minor traumatic brain injury? Ann Fr Anesth Reanim 2009;28(2):135-139. DOI: 10.1016/j. annfar.2008.12.019.

43. Korfias S, Stranjalis G, Boviatsis E, et al. Serum S-100B protein monitoring in patients with severe traumatic brain injury. Intensive Care Med 2007;33(2):255-260. DOI: 10.1007/s00134-0060463-4.

44. Carney N, Totten AM, Hawryluk GWJ, et al. Guidelines for the management of severe. Traumatic Brain Injury. 4th ed., 2016.

45. Chesnut RM, Temkin N, Carney N, et al. A trial of intracranial-pressure monitoring in traumatic brain injury. N Engl J Med [Internet] 2012;367(26):2471-2481. Available from: http://www.nejm.org/doi/ abs/10.1056/NEJMoa1207363.

46. Bonow RH, Barber J, Temkin NR, et al. The outcome of severe traumatic brain injury in latin America. World Neurosurg 2018;111:2-5. DOI: 10.1016/j.wneu.2017.11.171.

47. Chesnut RM, Temkin N, Dikmen S, et al. A method of Managing severe traumatic brain injury in the absence of intracranial pressure monitoring: the imaging and clinical examination protocol. J Neurotrauma [Internet] 2017;35(1):54-63. DOI: 10.1089/ neu.2016.4472.

48. Hendoui N, Beigmohammadi MT, Mahmoodpoor A, et al. Reliability of calcium-binding protein $\mathrm{S100B}$ measurement toward optimization of hyperosmolal therapy in Traumatic Brain Injury. Eur Rev Med Pharmacol Sci 2013;17(4):477-485.

49. Shakeri M, Mahdkhah A, Panahi F. S100B protein as a post-traumatic biomarker for prediction of brain death in association with patient outcomes. Arch Trauma Res 2013;2(2):76-80. DOI: 10.5812/atr.8549.

50. Thelin EP, Jeppsson E, Frostell A, et al. Utility of neuron-specific enolase in traumatic brain injury; relations to $\mathrm{S100B}$ levels, outcome, and extracranial injury severity. Crit Care 2016;20(1):285. DOI: 10.1186/ s13054-016-1450-y.

51. Doha N, Ammar A, El-Mashad M, et al. Traumatic brain injury: serum $\mathrm{S}-100 \mathrm{~B}$ protein measurement related to neuroradiological findings. Menoufia Medical Journal 2019;32(2):417-422. DOI: 10.4103/mmj. mmj_564_17.

52. Park SH, Hwang SK. Prognostic value of serum levels of S100 calciumbinding protein $B$, neuron-specific enolase, and interleukin- 6 in pediatric patients with traumatic brain injury. World Neurosurgery 2018;118:e534-e542. DOI: 10.1016/j.wneu.2018.06.234.

53. Yalcin A, Baydin A, Tuncel Ö, et al. Diagnostic values of proenkephalin and $\mathrm{S} 100 \mathrm{~B}$ protein in traumatic brain injury. Journal of Laboratory Medicine 2017;41(3):123-128. DOI: 10.1515/labmed-20160045.

54. Vos PE, Jacobs B, Andriessen TMJ, et al. GFAP and S100B are biomarkers of traumatic brain injury. Neurology 2010;75(20): 1786-1793. DOI: 10.1212/WNL.0b013e3181fd62d2. 